\section{AS LESÕES ESPORTIVAS COMO CONCEITO DO TREINAMENTO ATLÉTICO}

0 leitor brasileiro que queira estudar os conceitos do treinamento atlético (TA) não deve ler este livro, que se intitula exatamente conceitos do TA. Primeiramente, há a questão lingüística (o traduttore, traditore!): em português entendemos TA como 0 processo pelo qual se desenvolvem as potencialidades que permitem 0 alcance da performance de alto desempenho; já em inglês norte-americano a expressão se refere mais à formação técnica do profissional que assessora as diferentes dimensões do esporte, enquanto fenômeno de expressão social e cultural. 0 ra, neste texto, com efeito, o tema que aqui se trata são as lesões desportivas (LD) em múltiplos componentes básicos, sobretudo clínicos, epidemiológicos, preventivos, profissionais e legais. Embora possa não parecer à primeira vista, a explicação para esse aparente paradoxo é a um só tempo simples e simbólica: é que se tomam os mencionados elementos como a própria identidade do TA adequado!

Estruturalmente, o plano de redação do livro está baseado em 20 capítulos e oito anexos. Daqueles, os oito iniciais dedicam-se a rever conceitos gerais so bre abo rdagens clássicas das LD , agregando-se às já citadas anteriormente, a nutricional, a emergencial, a médica, a fisiopatológica e a reabilitacional. $Q$ uanto às noções especificamente nosográficas, objeto dos subseqüentes, as LD são seqüenciadas em disposição topográfica, como, de resto, na maioria das iniciativas congêneres, deslocando-se pelos agravos dos segmentos superio res para os inferiores. No interior de cada um deles, os traumatismos decorrentes da prática desportiva são efetivamente tratados, a partir de respectivos substratos anatômicos e amplamente ilustrados por cifras de prevalência e incidência da prática norteamericana de diferentes modalidades, num nível de complexidade bastante satisfatório: não há detalhes minudicentes dos especialistas e nem o receio de encarar situações eventualmente assustadoras ao absolutamente jejuno.

À guisa de exemplo, assim é que nos reencontramos com a síndrome do segundo impacto, no trecho que trata das LD à cabeça, pescoço e face, correspondendo ao quadro decorrente de nova contusão antes da resolução completa de uma concussão cerebral. Da mesma forma, no referente aos acometimentos da coluna, situam-se a espondilólise e seu agravamento, e a espondilolistese, devidamente manejadas.

$\mathrm{N}$ a região do ombro, pontuam-se as fraturas de clavícula e das articulações gleno-umeral e esterno-clavicular, além de entorses e contusões locais, com seus determinantes, manifestações e decorrências. Em relação ao braço, punho e mão, condições sobejamente conhecidas, como a epicondilite lateral ("do cotovelo de tenista"), coexistem com problemas singulares, como a doença de $D$ ' $Q$ uervain, a tenosinovite que atinge os tendões do extensor breve e do abdutor longo do polegar na altura do processo estilóide do rádio, em decorrência ao uso excessivo e não orientado. $\mathrm{N}$ a bacia e pelve são lembradas distintamente a osteíte pubiana, processo degenerativo crônico também resultante de over use, a dolorida e perigosa contusão testicular e as hérnias, mais freqüentes nos homens e mais femurais nas mulheres. Controvérsias igualmente são trazidas, como a adoção de joelheiras, equipamentos de proteção individual, que, segundo algumas fontes citadas, reduziriam a frequência de $L D$, segundo outros, não; outros ainda não dizem que sim nem que não; na dúvida, porém, muitos os preconizam: não é nosso caso, posto que advo gamos o uso de equipamentos de proteção coletiva.

O utros agravos desportivos de interesse são tratados a seguir, como as principais afecções cardiopulmonares, vésicouretrais e gastrodigestivas. As moléstias dermatológicas merecem abordagem própria, assim como as decorrentes às alterações de temperatura (cãimbras, exaustão e ataque térmico - heatstroke -, hipotermia e congelamento), as doenças infecciosas mais pertinentes, diabetes, epilepsia, além de algumas especificidades do período da adolescência, como peculiaridades ligamentares, crescimento cartilagíneo, diagnósticos diferenciais e efeitos do treinamento de força.

Há apêndices com matérias interessantes e úteis, como protocolo muito adequado de ressuscitação cardiopulmonar (mais muito mesmo!) e outro sobre contaminação sangüínea nos espo rtes, listagem de itens para caixa de socorros e material para aplicação de equipamentos, além de glossário e índice remissivo.

Globalmente visto, o texto apresenta inúmeros outros aspectos bastante sensíveis, principalmente a abordagem e a linguagem acessíveis: abrange variado espectro de leitores composto por treinadores, professores de educação física envolvidos com oportunidades aplicadas de exercício profissional, alunos de graduação, especialistas em formação, candidatos a ingresso a cursos de titulação acadêmica e até mesmo mestrandos e doutorandos aos quais seja desejável suplantar lacunas em áreas conexas de seus interesses específicos.

As idéias fundamentais são introduzidas a partir de conceituações norte-americanas institucionais respeitáveis, como da Associação $\mathrm{N}$ acional de Treinadores Atléticos ( $\mathrm{N}$ ata), Asso ciação Atlética N acional Colegiada (N C AA), Sistema N acional de Vigilância de Lesões (ISS), Pesquisa $N$ acional de Lesões na Escola Secundária, Comitê de Aspectos Médicos do Esporte, Associação Médica Americana (AMA), N omenclatura Padrão de Lesões Atléticas (SN Al) e Conselho Nacional de Segurança ( N SC), entre muitas outras. D evidamente submetidas à remissão nas respectivas referências bibliográficas, tais obras testemunham o tratamento atribuído no âmbito normativo federal dos Estados U nidos, contrariamente ao que ocorre entre nós.

$\mathrm{N}$ este contexto, os dados estatístico-sanitários explicitados são profusos e aparentemente confiáveis: ambos os autores, 
docentes de Departamento de $C$ iensiologia em duas universidades daquele país, expressam, nas partes iniciais, paradigmas básicos e apreciações críticas convincentes do repertório epidemiológico, versando acerca de fatores de risco e delineamentos observacionais, principalmente retrospectivos (i.e., ensaios do tipo caso-controle). E, realmente, são reveladoras as menções de que, na realidade nacio nal indicada, "apesar das alterações de regras, supervisão adequada e treinamento aprimorado, especialistas relatam que $3 \%$ a $11 \%$ de to das as crianças sofrem anualmente algum tipo de LD". Como dimensionar tais achados em relação ao que ocorre em nosso meio: nossos escolares são menos violentos e se lesam menos, ou mais ativos e se vitimam mais? 0 concreto é que nem sequer dispomos de tais informações, para poder, ao mínimo, comparar realidades!

Característica peculiar detectável é a preocupação formal elaborada em relação a recursos para aprendizagem, amplamente adotados em cada capítulo. $\mathrm{N}$ a correspondente folha de rosto há resumo orientador, não só indicativo mas descritivo e com algumas pistas analíticas, bastante informativo: aí também figura(m) o(s) endereço(s) da(s) mais relevante(s) organização(ões) relacionada(s) ao tema em pauta. Boxes, estrategicamente alocados ao longo do texto, I) propõem situações-problemas para consideração, do tipo "que orientações fornecer em caso de... "; II) recuperam nominatas de diretrizes operacionais para situações prioritárias; III) reproduzem declarações de relevância da área sobre conteúdos tratados; IV) expõem figuras e quadros bastante ilustrativos; e V) indicam itens de revisão para fixação e discussão.

Procedimento nesse sentido que importa destacar consiste na clareza, pragmatismo e diretividade empregadas em trechos que implicam condutas a serem tomadas ou intervenções a serem executadas, como é o caso do exame preventivo periódico e demais ações profiláticas para o controle dos fatores extrínsecos das LD (capítulo 4). De fato, em circunstâncias desse tipo, são trazidas possibilidades que permitem, ao leitor dedicado, aquisição de razoável automatismo na execução das medidas preconizadas pelos respectivos protocolos.

Talvez neste agir resida uma das limitações do que aqui se aprecia: 0 excesso de didatismo, na medida em que, muito freqüentemente, uma única conotação é repetida tantas vezes em determinado segmento que a leitura pode resvalar para 0 movediço terreno do desinteresse.

Mais que isso: riscos maiores há, como o de superficialismo. Ao tratar do que pretensamente é chamado de "psicologia do esporte", a centralidade do interesse está situada, a julgar pela proporcionalidade de páginas dedicadas ao tema (mais da metade!), no trato das desordens da nutrição, especificamente a bulimia e a anorexia.

Evidentemente nenhum profissional que lida com a matéria pode ignorar tais manifestações. Importa, porém, conhecer fatos mais substantivos da área que inclusive as explicam, co mo o turbilhão de emoções contraditórias e conflitivas que afloram tão intensamente e amiúde em diferentes momentos e para distintos protagonistas do fenômeno desportivo, ou até outros, mais dirigidamente, como o medo de fracasso e a expectativa de sucesso, por constituírem a base de constructos que podem se investir em instrumentos esclarecedores para entendimento do significado psico ssocial das múltiplas faces e manifestaçõ es da atividade física competitiva contemporânea.

$Q$ uestões como essas, ou até a presença de viés de enfo que funcionalista dos autores saxônicos tão legitimamente aversivo a estudantes e estudiosos estruturalistas brasileiros, precisam ser mantidas em linha de perspectiva. $\mathrm{N}$ ão obstante, nesta fonte muitos de nós temos o que exaurir, sendo mesmo procedente a cogitação de sua eventual tradução ao português para que se amplie a potencial abrangência de seus usuários.

Aguinaldo Gonçalves Glauca G. Mantellinı Campinas - SP

Referência

Pfeiffer RP, Mangos BC. Concepts of athletic training. $3^{\text {rd }}$ ed. massachusetts: Jones \& Bartlett; 2002. 